\title{
ABNORMAL OTOLITHS IN THE MARINE FISHES COLLECTED FROM THE PERSIAN GULF AND THE GULF OF OMAN
}

\author{
Narges MANIZADEH, Azad TEIMORI*, Majid ASKARI HESNI, and Mina MOTAMEDI \\ Department of Biology, Faculty of Sciences, Shahid Bahonar University of Kerman, Kerman, Iran
}

\begin{abstract}
Manizadeh N., Teimori A., Askari Hesni M., Motamedi M. 2018. Abnormal otoliths in the marine fishes collected from the Persian Gulf and the Gulf of Oman. Acta Ichthyol. Piscat. 48 (2): 143-151.

Background. Although several researchers have examined otoliths of marine fishes from the Persian Gulf and the Gulf of Oman, none has reported abnormalities. A recent effort to identify stocks of marine fishes of the Persian Gulf and the Gulf of Oman revealed that several species have abnormal otoliths. This is the first study reporting and describing the occurrence of abnormal otoliths from the fishes collected from the Persian Gulf and the Gulf of Oman.

Material and methods. A total of 225 fish specimens belong to 83 species and 33 families were randomly sampled from the Persian Gulf and the Gulf of Oman. The standard lengths (SL) were measured to the nearest $0.5 \mathrm{~mm}$. The otoliths were extracted, cleaned, and described following available literature. The specimens and their otoliths were deposited in the Zoological Museum at Shahid Bahonar University of Kerman (ZM-SBUK).

Results. Among the studied 83 species, we found six species having abnormal otoliths $(4.8 \%$ of the studied specimens). They belong to six families; Carangidae, Chanidae, Chirocentridae, Leiognathidae, Paralichthyidae, and Sparidae. The number of specimens with abnormal otoliths only in one side (either right or left side) was six, and those with abnormal otoliths in both sides was five. The left otoliths presented more extreme changes than the right. The observed abnormalities can be classified into three types; asteriscus attached to sagittal (the most common); otoliths with a more translucent or crystalline appearance in surface or outlines; and those with an abnormality in their sulcus region.

Conclusions. Ecologically, the Persian Gulf is an environment having various kinds of stresses such as salinity fluctuation, acidification, and the water temperature. Such stressors probably affect otolith formation during the larval stages of these fishes and are responsible for the observed abnormalities.
\end{abstract}

Keywords: sagitta, asteriscus, anomalous otolith, marine fish, Persian Gulf, Sea of Oman

\section{INTRODUCTION}

The otoliths or ear-stones are interesting hard structures which develop within the inner ear of bony fishes. They serve an important role in hearing and hydrodynamic balance (Popper et al. 2005). Otoliths are a set of three pairs of calcified structures including; sagitta, lapillus, and asteriscus. Sagitta (or saccular otolith) is the largest one in the majority of teleost fishes, and the main type that has been studied (Fig. 1). The stone-like otoliths of teleost fishes are composed of a calcium carbonate and small fraction of organic molecules such as proteins (Campana 1999).

Otolith morphology, particularly sagittal otolith, is usually genus- and species-specific and, therefore has been used extensively for taxonomic studies (Nolf 1985, Smale et al. 1995, Volpedo and Echeverría 2000, Lombarte et al. 2006, Schulz-Mirbach et al. 2006, Reichenbacher et al. 2007, Jawad et al. 2008, Teimori et al. 2012a Tuset et al. 2008, 2012) and also for reconstruction of phylogenetic relations in different groups of fishes (Nolf and Tyler

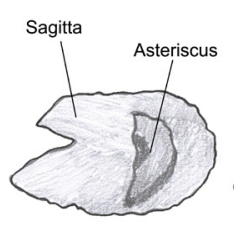

Type I

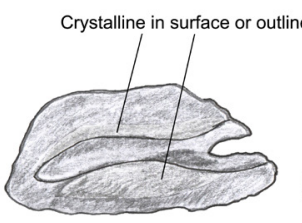

Type II

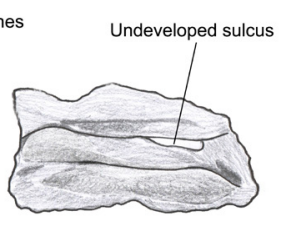

Type III
Fig. 1. The three patterns of abnormality seen in the otoliths of fishes collected from the Persian Gulf and the Gulf of Oman; type I shows the asteriscus attaching to the sagittal otolith, type II shows otoliths with crystalline appearance in surface or outlines, and type III) few otoliths show abnormality in their sulcus region

2006, Knudsen et al. 2007, Lombarte et al. 2010). Their isotopic chemistry also provides a microsample of water quality at the time of their deposition, and therefore is important, particularly when addressing potential 
environmental stresses (Campana 1999). In addition, variations in the otolith size and its contour have been used to discriminate populations or stocks (Lombarte and Castellón 1991, Campana and Casselman 1993, Torres et al. 2000, Stransky et al. 2008). Therefore, for a long time, otolith morphology has long been regarded as providing valuable information concerning the diversification of different fish groups (Schulz-Mirbach et al. 2006, Teimori et al. 2012a, 2012b, Tuset et al. 2016) and otolith shapes are generally regarded as scarcely influence by environmental factors (Lombarte and Lleonart 1993, Vignon and Morat 2010).

Nevertheless, otolith shapes do vary among individuals and some variations can be interpreted as abnormalities. Abnormal otoliths have been reported in various fishes from both marine and freshwater ecosystems (Gauldie 1993, Sweeting et al. 2004). Abnormal otoliths usually have shapes and relative transparency that differ from those seen in normal otoliths.

Although several authors (Mansourkiaei 2010, Sadighzadeh et al. 2014, 2017, Javadzadeh et al. 2015, 2016) have examined the otoliths of marine fishes from the Persian Gulf and the Gulf of Oman, none reported abnormalities. A recent effort to identify stocks of marine fishes of the Persian Gulf and the Gulf of Oman revealed that several species have abnormal otoliths. This is the first report of abnormal otoliths occurring in species collected from this region.

\section{MATERIALS AND METHODS}

Collection of fish specimens. A total of 225 marine fish specimens representing 83 species and 33 families were randomly caught by demersal and midwater trawl from coastal waters of the Persian Gulf and the Gulf of Oman within November 2015 through November 2016. In addition, some of the specimens were provided from the main fish market of the Bandar Abbas city. The standard lengths (SL) were measured to the nearest $0.5 \mathrm{~mm}$. All the collected specimens were deposited in the Zoological Museum at Shahid Bahonar University of Kerman (ZMSBUK).

Otolith examination and terminology. To examine otolith morphology, fish skulls were opened ventrally and right and left otoliths were extracted. Otoliths were cleaned from tissue remains in $1 \%$ potassium hydroxide $(\mathrm{KOH})$ solution for $6 \mathrm{~h}$ and then rinsed in distilled water for $12 \mathrm{~h}$. They were positioned on plasticine with the lateral face down, and digital images were captured using a Dino-Lite imaging system (AM-432X) connected to a stereomicroscope (SZ-ST).

Abnormal otoliths were defined based on their external shape and appearance, which were characterized by the attaching of two otoliths to each other (i.e., asteriscus attached to sagittal), and with a more translucent or crystalline appearance compared to the normal otoliths. The otolith terminology followed Tuset et al. (2008).

\section{RESULTS}

Otolith abnormality. A total of 450 sagittal otoliths were extracted from 225 fish specimens. Of these, 11 specimens $(4.8 \%)$ had a total of 15 abnormal otoliths on one or both sides (Table 1). The fishes with abnormal otoliths belong to six species; Parastromateus niger (Bloch, 1795) (Carangidae); Chanos chanos (Forsskål, 1775) (Chanidae); Chirocentrus nudus Swainson, 1839 (Chirocentridae); Leiognathus equulus (Forsskål, 1775) (Leiognathidae); Pseudorhombus malayanus Bleeker, 1865 (Paralichthyidae); and Diplodus kotschyi (Steindachner, 1876) (Sparidae). The number of individuals with abnormal otoliths only on one side (right or left side) was six, and the number of those with abnormal otoliths on both sides was five. The percentage

Overview on the studied fish species, individuals and their abnormal otoliths

Table 1

\begin{tabular}{|c|c|c|c|c|c|c|c|c|c|}
\hline \multirow{3}{*}{ Family } & \multirow{3}{*}{ Species } & \multirow{3}{*}{$n_{1}$} & \multirow{3}{*}{$n_{2}$} & \multirow{2}{*}{$\begin{array}{l}\text { Catalog numbers; } \\
\text { studied }\end{array}$} & \multirow{3}{*}{$\mathrm{SL}[\mathrm{mm}]$} & \multicolumn{3}{|c|}{$\begin{array}{c}\text { No. of abnormal } \\
\text { otoliths }\end{array}$} & \multirow{3}{*}{$\begin{array}{c}\text { Abnormal } \\
\text { otoliths } \\
{[\%]}\end{array}$} \\
\hline & & & & & & \multicolumn{2}{|c|}{ On one side } & \multirow{2}{*}{$\begin{array}{l}\text { On two } \\
\text { sides }\end{array}$} & \\
\hline & & & & $\begin{array}{c}\text { Catalog numbers; } \\
\text { abnormal }\end{array}$ & & Left & Right & & \\
\hline Carangidae & Parastromateus niger & 4 & 1 & $\begin{array}{l}\text { ZM-SBUK100-103 } \\
\text { ZM-SBUK-102 }\end{array}$ & $193.08 \pm 6.8$ & 1 & 0 & 0 & 12.5 \\
\hline Chanidae & Chanos chanos & 4 & 1 & $\begin{array}{l}\text { ZM-SBUK104-107 } \\
\text { ZM-SBUK-107 }\end{array}$ & $227.84 \pm 10.5$ & 0 & 0 & 1 & 12.5 \\
\hline Chirocentridae & Chirocentrus nudus & 2 & 1 & $\begin{array}{l}\text { ZM-SBUK108-109 } \\
\text { ZM-SBUK109 }\end{array}$ & $370.26 \pm 14.8$ & 1 & 0 & 0 & 25.0 \\
\hline Leiognathidae & Leiognathus equulus & 3 & 2 & $\begin{array}{l}\text { ZM-SBUK110-112 } \\
\text { ZM-SBUK110, } 112\end{array}$ & $163.81 \pm 8.3$ & 0 & 0 & 2 & 33.3 \\
\hline Paralichthyidae & $\begin{array}{l}\text { Pseudorhombus } \\
\text { malayanus }\end{array}$ & 3 & 3 & $\begin{array}{l}\text { ZM-SBUK113-115 } \\
\text { ZM-SBUK113-115 }\end{array}$ & $221.72 \pm 12.8$ & 3 & 0 & 0 & 50.0 \\
\hline Sparidae & Diplodus kotschyi & 3 & 3 & $\begin{array}{l}\text { ZM-SBUK116-118 } \\
\text { ZM-SBUK116-118 }\end{array}$ & $159.42 \pm 10.3$ & 0 & 1 & 2 & 50.0 \\
\hline
\end{tabular}

SL values are mean \pm standard deviation; $n_{1}=$ number of fish examined, $n_{2}=$ number of fish with abnormal otoliths. 
of abnormal otoliths in each individual species is shown in Table 1.

Generally, the observed abnormalities represented three categories:

- Asteriscus attached to sagittal otolith

- Otoliths with more translucent or crystalline appearance in surface or outlines

- Otoliths with an abnormality in their sulcus region (Fig. 1).

Abnormalities representing the first category occurred in otoliths of Chirocentrus nudus, Parastromateus niger, and Pseudorhombus malayanus. The second-category abnormalities occurred in Diplodus kotschyi, Chanos chanos, and Pseudorhombus malayanus. The sulcus from the left otoliths of two specimens of Leiognathus equulus were incompletely developed, with additionally a few white crystal-like structures present on their proximal sides.

Description of the otoliths and abnormality. The normal and abnormal otoliths are described below for each individual species.

Family: Carangidae

Parastromateus niger (Bloch, 1795)

Normal otoliths. Shape lanceolated, outline lobed. Sulcus acusticus ostial and median. Ostium funnellike, shorter than cauda. Cauda tubular, ending close to posterior margin. Posterior region oblique. Rostrum long. Antirostrum short. Excisura wide (Figs. 2A-2B).

Abnormal otoliths. Asteriscus attached to anterior region of distal surface of left otolith (Fig. 2C). Shape lanceolated, outline lobed. Posterior region oblique. Rostrum short. Antirostrum weak.

Family: Chanidae

Chanos chanos (Forsskål, 1775)

Normal otoliths. Shape lanceolated; sulcus acusticus ostial median; ostium funnel like; cauda straight. Posterior region doubled peaked; rostrum pointed; antirostrum short, pointed peaked (Figs. 3A-3B).

Abnormal otoliths. Elongated prominence existing along distal surface of antirostrum in both right and left otoliths
(Figs. 3C-3F). Shape lanceolated; sulcus acusticus ostial median; ostium funnel like; cauda straight. Posterior region doubled peaked; rostrum pointed; antirostrum short, pointed. Family: Chirocentridae

Chirocentrus nudus Swainson, 1839

Normal otoliths. Shape rectangular, sulcus acusticus funnel like, slightly curved. Rostrum long and relatively narrow. Antirostrum pointed and short. Excisura broad and wide. Posterior region round (Figs. 4A-4B).

Abnormality. Asteriscus attached to distal surface of left sagitta (Fig. 4C). Shape rectangular. Sulcus acusticus funnel like, slightly curved. Rostrum long and relatively narrow. Antirostrum pointed and short. Excisura broad and wide. Posterior region round.

Family: Leiognathidae

Leiognathus equulus (Forsskål, 1775)

Normal otoliths. Shape rectangular. Sulcus acusticus funnel like. Cauda slightly curved. Rostrum round lobed. Antirostrum short, pointed. Posterior region oblique (Figs. $5 \mathrm{~A}-5 \mathrm{~B})$.

Abnormal otoliths. Sulcus acusticus unformed (not well developed) on proximal side of otoliths (Figs. 5C-5D). White sediments existing on proximal side of otoliths (Figs. 5C-5F). Shape rectangular. Sulcus acusticus funnel like. Cauda slightly curved. Rostrum round-lobed. Antirostrum short, pointed; Posterior region straight (Figs. 5C-5D) or oblique (Figs. 5E-5F).

Family: Paralichthyidae

Pseudorhombus malayanus Bleeker, 1865

Normal otoliths. Shape rectangular. Sulcus acusticus straight. Rostrum short, rounded. Antirostrum unspecified. Posterior region flattened (Figs. 6A-6B).

Abnormal otoliths. Asteriscus attached to anterior region of proximal surface of sagittal (Figs. 6C), and also to distal surface (Figs. 6D-E). Undefined crystal structure existing on distal surface of sagitta (Fig. 6E). Shape oval or rectangular. Sulcus acusticus straight. Rostrum weak. Antirostrum unspecified. Posterior region flattened or rounded (Figs. 6C-6E).

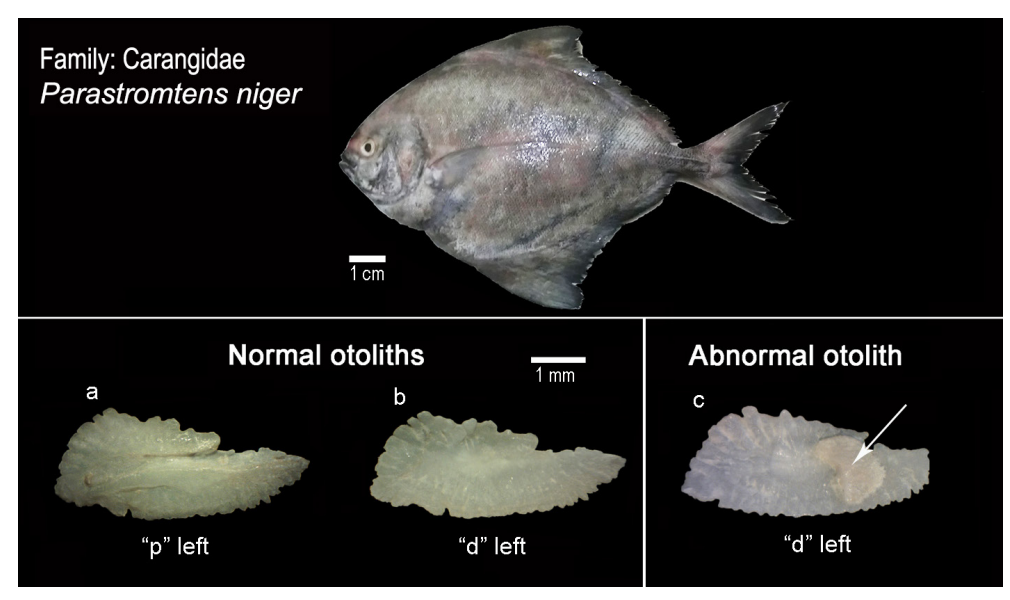

Fig. 2. Description of the normal (A-B) and abnormal $(\mathbf{C})$ otoliths in the Parastromateus niger; "d" refers to the distal and " $p$ " to the proximal surfaces of the otoliths; the arrow indicates pattern of abnormality (asteriscus attached to the sagittal) 


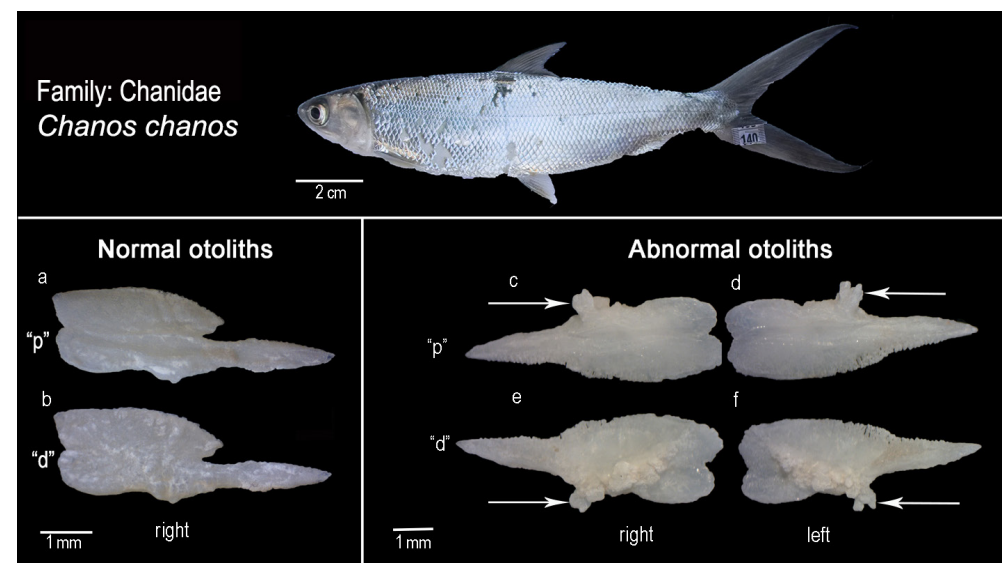

Fig. 3. Description of the normal $(\mathbf{A}-\mathbf{B})$ and abnormal $(\mathbf{C}-\mathbf{F})$ otoliths in the Chanos chanos; "d" refers to the distal and "p" to the proximal surfaces of the otoliths; the arrows indicate elongated prominence along the distal surface of the antirostrum in both right and left otoliths

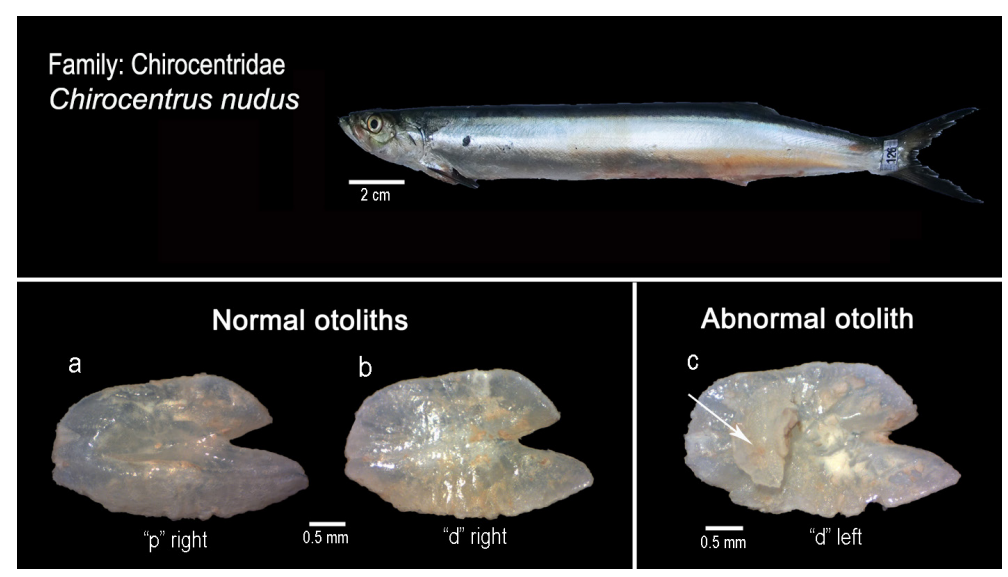

Fig. 4. Description of the normal $(\mathbf{A}-\mathbf{B})$ and abnormal $(\mathbf{C})$ otoliths in the Chirocentrus nudus; "d" refers to the distal and "p" to the proximal surfaces of the otoliths; the arrow indicates pattern of abnormality (asteriscus attached to the sagittal)

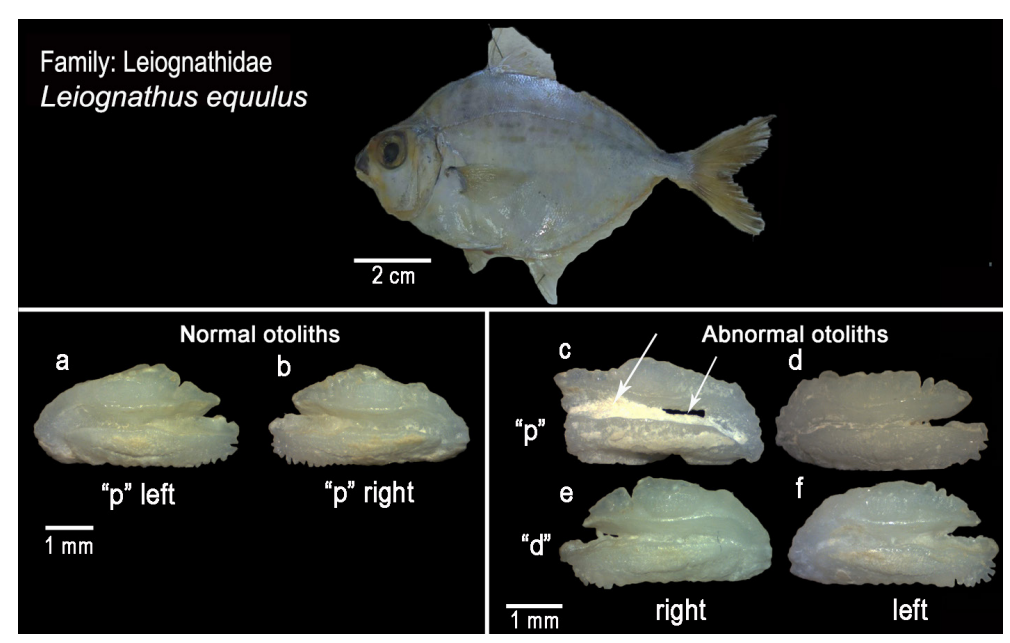

Fig. 5. Description of the normal (A-B) and abnormal otoliths in the Leiognathus equulus; abnormalities in the otoliths of this species are in two types; sulcus acusticus do not developed well on the proximal side $(\mathbf{C}-\mathbf{D})$, and the presence of white sediments on the proximal side $(\mathbf{C}-\mathbf{F})$; " $d$ " refers to the distal and "p" to the proximal surfaces of the otoliths; the arrows indicate abnormality in sulcus 


\section{Family: Sparidae}

Diplodus kotschyi (Steindachner, 1876)

Normal otoliths. Shape elliptic to oblong with conspicuous spike in middle of dorsal margin delimiting two shallow concavities. Sulcus acusticus heterosulcoid, ostial, median. Ostium funnel-like, shorter than or as long as cauda. Cauda tubular, curved, markedly flexed posteriorly, ending close to posteroventral margin. Posterior region oblique. Rostrum broad, short, pointed to round. Antirostrum absent. Excisura wide without notch (Figs. 7A-7B).

Abnormal otoliths. Several prominences exist on the distal surfaces of abnormal otoliths (Figs. 7C-7G). Shape elliptic to oblong with conspicuous spike in middle of dorsal margin delimiting two shallow concavities. Posterior region straight. Rostrum thick, short, pointed. Antirostrum not developed.

\section{DISCUSSION}

Otoliths play an important role in the in hearing and in maintaining hydrodynamic balance, as part of the mechanism for sensing gravity, linear acceleration, and sound detection (Popper and Lu 2000). These functions are particularly important for fishes, which live in a three-dimensional aqueous medium and thus, important for survival. However, otoliths do not always develop uniformly and abnormalities of various types have been described (Lombarte and Lleonart 1993, Gagliano and McCormic 2004, Mérigot et al. 2007, Hüssy 2008, Jessop et al. 2008). Abnormal otoliths have been reported in various fish families, including the Engraulidae, Clupeidae, Salmonidae, Ophidiidae, Macrouridae, Gadidae, Moronidae, Pleuronectidae, Soleidae, and Sciaenidae (see Palmork et al. 1963, Wilson 1985, Strong et al. 1986, Dierking et al. 2012, Vinagre et al. 2014b). This report adds to this list and provides the first records from species in the Persian Gulf and the Gulf of Oman.
Differences in the ratio of abnormal to normal otoliths have been reported between wild caught and captive fish populations. Gauldie $(1986,1993,1996)$ reported $34 \%$ abnormalities in captive juvenile Chinook salmon. Bowen et al. (1999) reported 26\%-41\% abnormal otoliths for stocked lake trout. In contrast, the percentages of $1.0 \%-5.5 \%$ abnormal otoliths were observed among in wild-caught individuals of these species (Blacker 1974, Morales-Nin 1985, Strong et al. 1986, Tomás and Geffen 2003). A value of $4.8 \%$ for all specimens examined in this study is consistent with previous findings for wildcaught fishes. However, values for the six species based on limited samples listed in Table 1, suggest much higher percentages of abnormal otoliths than expected.

In our study, the majority of abnormal types was the attachment of asteriscus to sagittal otoliths (type I) and followed by the high amount of granulations or undefined crystal structures on otoliths (type II).

The attachment of asteriscus to sagittal otolith is a rare event in developmental processes of otoliths. However, in some fishes, lagena (the membrane vesicles of asteriscus) is almost laterally attached to the saccule (the membrane vesicles of sagittal) (Fig. 8). Therefore, it might be possible that asteriscus becomes a part of sagitta during earlier stages of development. In the studied specimens, asteriscus looked morphologically quite normal as did the sagitta. This would imply that both otoliths had normal initial phases of development. Additionally, it is likely that asteriscus became detached from its own macula by a trauma and then was attached to sagitta during further growth. If both otoliths had been attached in a very early stage of development, it can be expected that asteriscus show less of its own characteristic shape; it should then be rather a merged strange looking "sacculoasterisc" otolith.

The individual size ranges for each studied species with abnormal otoliths was shown in Table 1. But since the

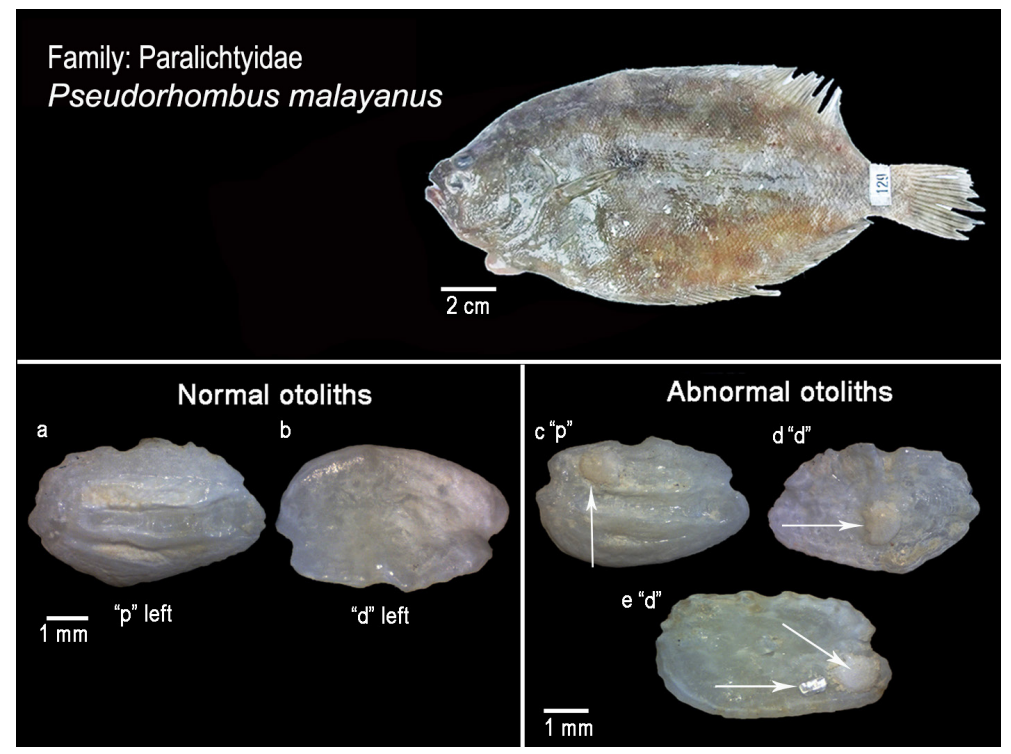

Fig. 6. Description of the normal (A-B) and abnormal otoliths in the Pseudorhombus malayanus; asteriscus is attached to the anterior region of proximal $(\mathbf{C})$ and distal $(\mathbf{B})$ surfaces of the sagitta (they showed with arrows); an undefined crystal structure exists on distal surface of the sagitta (in $\mathbf{E}$, it is pointed by an arrow); "d" refers to the distal and "p" to the proximal surfaces of the otoliths 


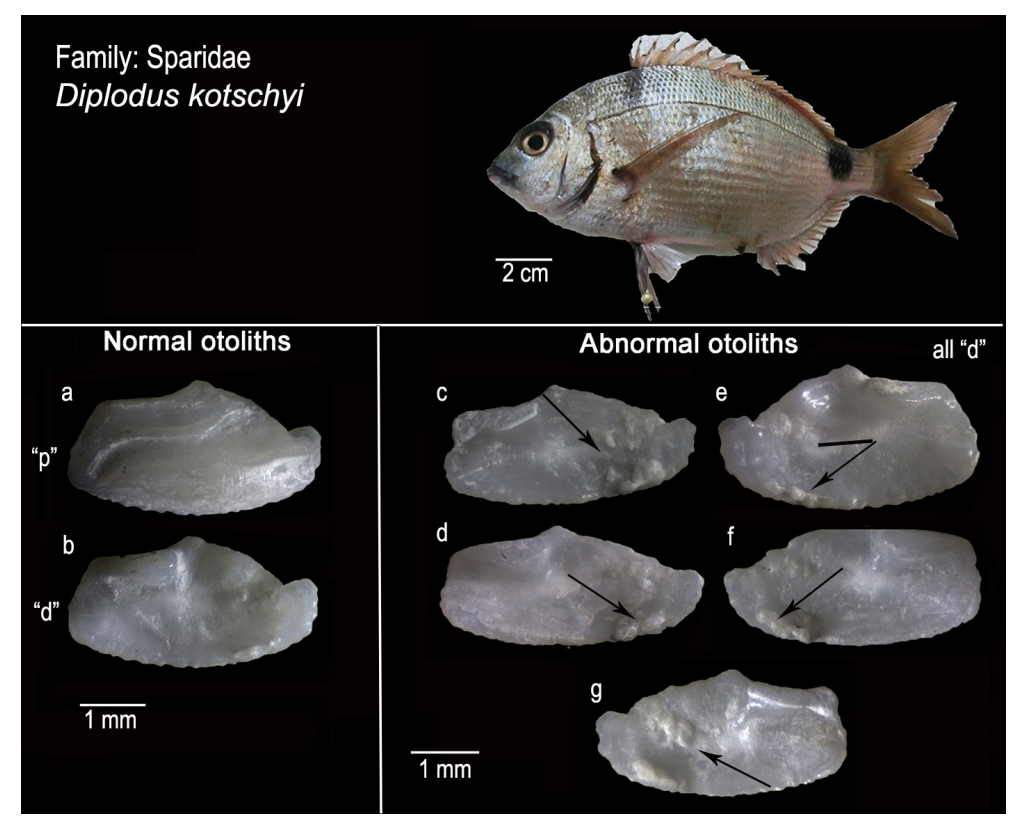

Fig. 7. Description of the normal $(\mathbf{A}-\mathbf{B})$ and abnormal $(\mathbf{C}-\mathbf{G})$ otoliths in the Diplodus kotschyi; there are several prominences on the distal surface of all the abnormal otoliths (they showed with arrows); "d" refers to the distal and "p" to the proximal surfaces of the otoliths

number of specimens with abnormal otoliths in our study was low, we, therefore, could not apply statistical analyses to examine if the rate of abnormality was related to the fish size. A study by Neves et al. (2015) on the juvenile flounder collected from the Minho River estuary (NW Portugal), suggested that the occurrence of anomalies was probably related to the fish size in which the rate of abnormality was higher for smaller fish (smaller than $7.5 \mathrm{~cm}$ ).

Our examination revealed that, in general, both the right and left otoliths showed abnormality with the left side presenting more extreme changes than the right (10 in the left side vs. six in the right side) (see also Table 1). This is in agreement with the results of Mugiya (1972) and Neves et al. (2015).

It has been shown that aragonite, the predominant form of $\mathrm{CaCO}_{3}$, is replaced with vaterite in abnormal otoliths, with vaterite having depleted concentrations of $\mathrm{Sr}, \mathrm{Na}$, and $\mathrm{K}$ in laboratory-reared juvenile herring (Tomás and Geffen 2003). Higher vaterite concentrations may affect the asymmetry, density, and size of otoliths, leading to hearing impairment in farmed fish (Tomás and Geffen 2003, Reimer et al. 2016).

A number of reasons have been suggested as the cause of otolith abnormality. Sweeting et al. (2004) hypothesized that metabolic rate may influence vaterite formation. Moreover, in their study, Béarez et al. (2005) have discussed the potential role of oceanic climatic disturbances such as upwelling phenomenon as a cause of otolith anomalies found in Sciaenidae from Peruvian coasts. Since no significant upwelling exists in the region studied in our project, therefore this could not be considered as a reason for the observed abnormalities. The most recent study by Vinagre et al. (2014b) has shown a high amount of granulations in the otoliths of wild Solea solea (Linnaeus, 1758) and
Solea senegalensis Kaup, 1858 (Family: Soleidae). The above-mentioned authors concluded that the stressful environmental conditions during the larval stage in coastal waters were possible reasons for those abnormalities.

Ecologically, the Persian Gulf has been considered as one of the most stressful environments regarding of the

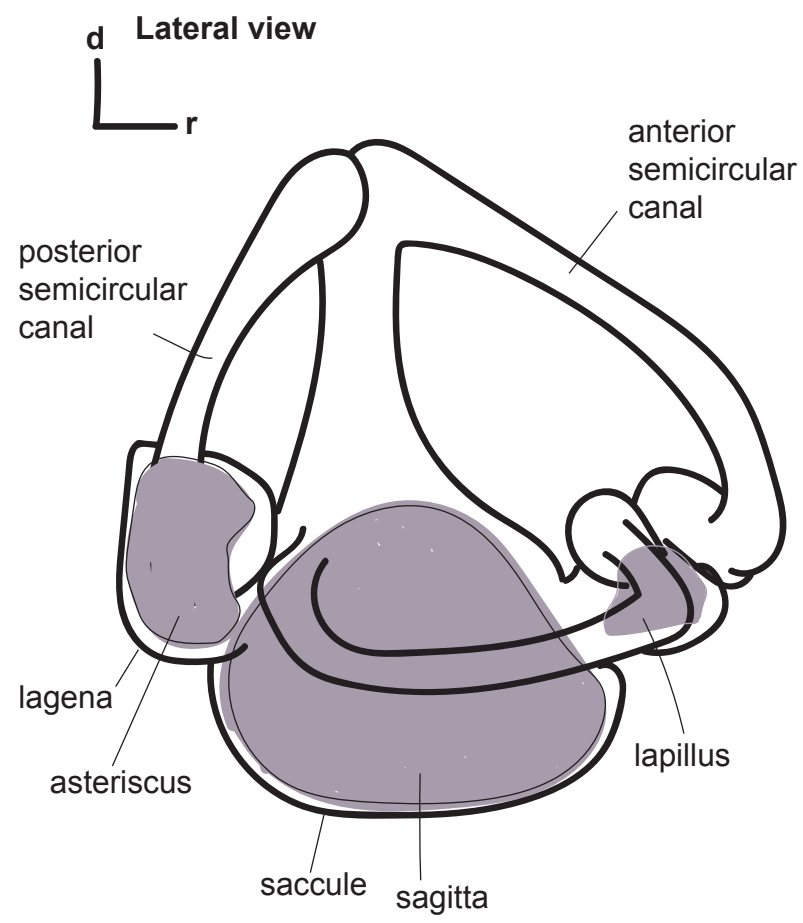

Fig. 8. The anatomical position of the lagena (containing asteriscus), which is almost laterally, attached to the saccule (containing sagittal); figure is modified from Schulz-Mirbach et al. 2011

"CIn the wake of the growing criticism of the Practical Salinity Scale concept (and especially PSU as a "unit"), Acta Ichthyologica et Piscatoria is in favour of expressing salinity in parts per thousand (\%), regardless if a direct or indirect method was employed to determine the water salinity. 
salinity fluctuation, acidification (Uddin et al. 2012) and probably water temperature which is ranging from 12 to $38^{\circ} \mathrm{C}$ (Bauman 2013). Additionally, the salinity of $>39 \%{ }^{*}$ predominates in the Persian Gulf waters (Sheppard et al. 2010). As these factors affect otolith formation (Neat et al. 2008, Munday et al. 2011, Vinagre et al. 2014a), it is suggested that fluctuations in these factors are possible reason of the abnormalities observed in this study. Nevertheless, a question still remains why only these six species had abnormalities, whereas other species among the 245 specimens from which otoliths were collected did not. To answer this question, examination of more individuals of the species and water parameters would be needed.

\section{ACKNOWLEDGEMENTS}

The authors would like to thank all students from the Animal Biosystematics Lab who were involved in the field and laboratory work, and the Shahid Bahonar University of Kerman (SBUK), for financial supporting of this work (grant number-1393-1394).

\section{REFERENCES}

Bauman A.G., Pratchett M.S., Baird A.H., Riegl B., Heron S.F., Feary D.A. 2013. Variation in the size structure of corals is related to environmental extremes in the Persian Gulf. Marine Environmental Research 84: 43-50. DOI: 10.1016/j.marenvres.2012.11.007

Béarez P., Carlier G., Lorand J.P., Parodi G.C. 2005. Destructive and non-destructive microanalysis of biocarbonates applied to anomalous otoliths of archaeological and modern sciaenids (Teleostei) from Peru and Chile. Comptes Rendus Biologies 328 (3): 243-252. DOI: 10.1016/j.crvi.2005.01.003

Blacker R.W. 1974. Recent advances in otolith studies. Pp. 67-90. In: Harden Jones F.R. (ed.) Sea fisheries research. John Wiley, New York, NY, USA.

Bowen C.A.II, Bronte C.R., Argyle R.L., Adams J.V., Johnson J.E. 1999. Vateritic sagitta in wild and stocked lake trout: Applicability to stock origin. Transactions of the American Fisheries Society 128 (5): 929 938. DOI: $10.1577 / 1548-8659(1999) 128<0929$ :VSIWAS $>2.0 . \mathrm{CO} ; 2$

Campana S.E. 1999. Chemistry and composition of fish otoliths: Pathways, mechanisms and applications. Marine Ecology Progress Series 188: 263-297.

Campana S.E., Casselman J.M. 1993. Stock discrimination using otolith shape analysis. Canadian Journal of Fisheries and Aquatic Sciences 50 (5): 1062-1083. DOI: 10.1139/f93-123

Dierking J., Morat F., Letourneur Y., Harmelin-Vivien M. 2012. Fingerprints of lagoonal life: Migration of the marine flatfish Solea solea assessed by stable isotopes and otolith microchemistry. Estuarine, Coastal and Shelf Science 104-105: 23-32. DOI: 10.1016/j. ecss.2011.03.018

Gagliano M., McCormick M.I. 2004. Feeding history influences otolith shape in tropical fish. Marine Ecology Progress Series 278: 291-296. DOI: 10.3354/ meps 278291
Gauldie R.W. 1986. Vaterite otoliths from chinook salmon (Oncorhynchus tshawytscha). New Zealand Journal of Marine and Freshwater Research 20 (2): 209-217. DOI: 10.1080/00288330.1986.9516145

Gauldie R.W. 1993. Polymorphic crystalline structure of fish otoliths. Journal of Morphology 218 (1): 1-28. DOI: $10.1002 /$ jmor.1052180102

Gauldie R.W. 1996. Effects of temperature and vaterite replacement on the chemistry of metal ions in the otoliths of Oncorhynchus tshawytscha. Canadian Journal of Fisheries and Aquatic Sciences 53 (9): 2015-2026. DOI: 10.1139/f96-123

Hüssy K. 2008. Otolith shape in juvenile cod (Gadus morhua): Ontogenetic and environmental effects. Journal of Experimental Marine Biology and Ecology 364 (1): 35-41. DOI: 10.1016/j.jembe.2008.06.026

Javadzadeh N., Mabudi H., Taghi Azhir M. 2016. Investigation of otolith's characteristics in Rachycentron canadum in the Persian Gulf and Oman Sea. Iranian Journal of Fisheries Sciences 15 (3): 973-979.

Javadzadeh N., Tagi Azhir M., Mabudi H. 2015. The study of otolith in two species of Drepanidae in Persian Gulf and Oman Sea. Pp. 34-37. In: 2nd International Conference on Advances in Environment, Agriculture and Medical Sciences (ICAEAM'15), 11-12 June 2015, Antalya, Turkey.

Jawad L.A., Al-Jufaili S.A., Al-Shuhaily S.S. 2008. Morphology of the otolith of the greater lizardfish Saurida tumbil (Pisces: Synodontidae). Journal of Natural History 42 (35-36): 2321-2330. DOI: $10.1080 / 00222930802130278$

Jessop B.M., Shiao J.C., Iizuka Y., Tzeng W.N. 2008. Prevalence and intensity of occurrence of vaterite inclusions in aragonite otoliths of American eels Anguilla rostrata. Aquatic Biology 2 (2): 171-178. DOI: $10.3354 / \mathrm{ab} 00047$

Knudsen E.W., Møller P.R., Gravlund P. 2007. Phylogeny of the snailfishes (Teleostei: Liparidae) based on molecular and morphological data. Molecular Phylogeny and Evolution 44 (2): 649-666. DOI: 10.1016/j.ympev.2007.04.005

Lombarte A., Castellón A. 1991. Interspecific and intraspecific variability in the genus Merluccius as determined by image analysis. Canadian Journal of Zoology 69 (9): 2442-2449. DOI: 10.1139/z91-343

Lombarte A., Chic O., Parisi-Baradad V., Olivella R., Piera J., García-Ladona E. 2006. A web-based environment for shape analysis of fish otoliths. The AFORO database. Scientia Marina 70 (1): 147-152. DOI: $10.3989 /$ scimar.2006.70n1147

Lombarte A., Lleonart J. 1993. Otolith size changes related with body growth, habitat depth and temperature. Environmental Biology of Fishes 37 (3): 297-306. DOI: 10.1007/BF00004637

Lombarte A., Palmer M., Matallanas J., GómezZurita J., Morales- Nin B. 2010. Ecomorphological trends and phylogenetic inertia of otolith sagittae in Nototheniidae. Environmental Biology of Fishes 89 (3-4): 607-618. DOI: 10.1007/s10641-010-9673-2 
Lombarte A., Rufino M.M., Sánchez P. 2006. Statolith identification of Mediterranean Octopodidae, Sepiidae, Loliginidae, Ommastrephidae and Enoploteuthidae based on warp analyses. Journal of the Marine Biological Association of the United Kingdom 86 (4): 767-771. DOI: $10.1017 / \mathrm{S} 0025315406013683$

Mansourkiaei A. 2010. Karborde morphometry va khosusyate morphologye otolith dar jodasazye gunehaye khanevadeh gishmahian dar khalije Fars va dariaye Oman. [Using otolith morphometric and morphology characteristics to identify carangids species in the Persian Gulf and Oman Sea.] Master's Thesis, Islamic Azad University, Science and Research Branch, Tehran, Iran. [In Farsi.]

Mérigot B., Letourneur Y., Lecomte-Finiger R. 2007. Characterization of local populations of the common sole Solea solea (Pisces, Soleidae) in the NW Mediterranean through otolith morphometrics and shape analysis. Marine Biology 151 (3): 997-1008. DOI: $10.1007 / \mathrm{s} 00227-006-0549-0$

Morales-Nin B. 1985. Características de los otolitos cristalinos de Genypterus capensis (Smith, 1847) (Pisces: Ophidiidae). Investigación Pesquera 49 (3): 379-386.

Mugiya Y. 1972. On aberrant sagittas of teleostean fishes. Japanese Journal of Ichthyology. 19 (1): 11-14. DOI: 10.11369/jji1950.19.11

Munday P.L., Hernaman V., Dixson D.L., Thorrold S.R. 2011. Effect of ocean acidification on otolith development in larvae of a tropical marine fish. Biogeosciences 8 (6): 1631-1641. DOI: 10.5194/bg8-1631-2011

Neat F.C., Wright P.J., Fryer R.J. 2008. Temperature effects on otolith pattern formation in Atlantic cod Gadus morhua. Journal of Fish Biology 73 (10): 2527-2541. DOI: 10.1111/j.1095-8649.2008.02107.x

Neves V., Guedes A., Campos J., Freitas V. 2015. Aberrant otoliths in juvenile flounder Platichthys flesus (L.). Frontiers in Marine Science. Conference Abstract: XV European Congress of Ichthyology. DOI: 10.3389/conf.fmars.2015.03.00106

Nolf D. 1985. Otolithi piscium. Handbook of paleoichthyology. Gustav Fischer, Stuttgart, New York.

Nolf D., Tyler J.C. 2006. Otolith evidence concerning interrelationships of caproid, zeiform and tetradontiform fishes. Bulletin de l'Institut royal des sciences naturelles de Belgique 76: 147-189.

Palmork K.H., Taylor M.E.U., Coates R. 1963. The crystal structure of aberrant otoliths. Acta Chemica Scandinavica 17 (5): 1457-1458. DOI: 10.3891/acta. chem.scand.17-1457

Popper A.N., Lu Z. 2000. Structure-function relationships in fish otolith organs. Fisheries Research 46 (1-3): 1525. DOI: 10.1016/S0165-7836(00)00129-6

Popper A.N., Ramcharitar J., Campana S.E. 2005. Why otoliths? Insights from inner ear physiology and fisheries biology. Marine and Freshwater Research 56 (5): 497-504. DOI: 10.1071/MF04267
Reichenbacher B., Sienknecht U., Küchenhoff H., Fenske N. 2007. Combined otolith morphology and morphometry for assessing taxonomy and diversity in fossil and extant killifish (Aphanius, $\uparrow$ Prolebias). Journal of Morphology 268 (10): 898-915. DOI: 10.1002/jmor.10561

Reimer T., Dempster T., Warren-Myers F., Jensen AJ., Swearer S.E. 2016. High prevalence of vaterite in sagittal otoliths causes hearing impairment in farmed fish. Scientific Reports 6: e25249. DOI: 10.1038/ srep25249

Sadighzadeh Z., Jawad L.A., Al-Marzouqi M. 2017. Fluctuating asymmetry in the otolith of the mugilid fish Liza kluzingeri (Day, 1888) from Persian Gulf near Bandar Abbas. Thalassia Salentina. 33 (2010-2011): 95-102. DOI: 10.1285/i15910725v33p95

Sadighzadeh Z., Tuset V.M., Dadpour M.R., OteroFerrer J.L., Lombarte A. 2014. Otolith atlas from the Persian Gulf and the Oman Sea fishes. Lambert Academic Publishing, Riga, Latvia.

Schulz-Mirbach T., Heß M., Plath M. 2011. Inner ear morphology in the Atlantic molly Poecilia mexicanaFirst detailed microanatomical study of the inner ear of a cyprinodontiform species. PLoS ONE 6 (11): e27734. DOI: 10.1371/journal.pone.0027734

Schulz-Mirbach T., Reichenbacher B., Yildirim M.Z., Atalay M.A. 2006. Otolith characteristics of species, subspecies, and populations of Aphanius Nardo, 1827 (Teleostei, Cyprinodontiformes) from Anatolia (Turkey). Journal of Natural History 40 (27-28): 1687-1705. DOI: 10.1080/00222930600964498

Sheppard C., Al-Husiani M., Al-Jamali F., Al-Yamani F., Baldwin R., Bishop J., Benzoni F., Dutrieux E., Dulvy N.K., Durvasula S R.V., Jones D.A., Loughland R., Medio D., Nithyanandan M., Pillingm G.M., Polikarpov I., Price A.R.G., Purkis S., Riegl B., Saburova M., Samimi Namin K., Taylor O., Wilson S., Zainal K. 2010. The Gulf: A young sea in decline. Marine Pollution Bulletin 60 (2010): 1338. DOI: 10.1016/j.marpolbul.2009.10.017

Smale M.J., Watson G., Hecht T. 1995. Otolith atlas of southern African marine fishes. Ichthyological Monographs No. 1. J.L.B. Smith Institute of Ichthyology. Grahamstown. DOI: 10.5962/bhl.title. 141860

Stransky C., Murta A.G., Schlickeisen J., Zimmermann C. 2008. Otolith shape analysis as a tool for stock separation of horse mackerel (Trachurus trachurus) in the Northeast Atlantic and Mediterranean. Fisheries Research 89 (2): 159-166. DOI: 10.1016/j. fishres.2007.09.017

Strong M.B., Neilson J.D., Hunt J.J. 1986. Aberrant crystallization of pollock (Pollachius virens) otoliths. Canadian Journal of Fisheries and Aquatic Sciences 43 (7): 1457-1463. DOI: 10.1139/f86-180

Sweeting R.M., Beamish R.J., Neville C.M. 2004. Crystalline otoliths in teleosts: Comparisons between hatchery and wild coho salmon (Oncorhynchus kisutch) in the Strait of Georgia. Reviews in Fish 
Biology and Fisheries 14 (3): 361-369. DOI: 10.1007/ s11160-005-3793-3

Teimori A., Jawad L.A., Al-Kharusi L.H., Al-Mamry J.M., Reichenbacher B. 2012a. Late Pleistocene to Holocene diversification and historical zoogeography of the Arabian killifish (Aphanius dispar) inferred from otolith morphology. Scientia Marina 76 (4): 637-645. DOI: $10.3989 /$ scimar.03635.26C

Teimori A., Schulz-Mirbach T., Esmaeili H.R., Reichenbacher B. 2012b. Geographical differentiation of Aphanius dispar (Teleostei: Cyprinodontidae) from southern Iran. Journal of Zoological Systematics and Evolutionary Research 50 (4): 251-337. DOI: 10.1111/j.1439-0469.2012.00667.x

Tomás J., Geffen A.J. 2003. Morphometry and composition of aragonite and vaterite otoliths of deformed laboratory reared juvenile herring from two populations. Journal of Fish Biology 63 (6): 13831401. DOI: $10.1111 /$ j.1095-8649.2003.00245.x

Torres G. J., Lombarte A., Morales-Nin B. 2000. Variability of the sulcus acusticus in the sagittal otolith of the genus Merluccius (Merlucciidae). Fisheries Research 46 (1-3): 5-13. DOI: 10.1016/S0165-7836(00)00128-4

Tuset V.M., Azzurro E., Lombarte A. 2012. Identification of Lessepsian fish species using the sagittal otolith. Scientia Marina 76 (2): 289-299. DOI: 10.3989/ SCIMAR.03420.18E

Tuset V.M., Farré M., Otero-Ferrer J.L., Vilar A., Morales-Nin B., Lombarte A. 2016. Testing otolith morphology for measuring marine fish biodiversity. Marine and Freshwater Research 67 (7): 1037-1048. DOI: $10.1071 / \mathrm{MF} 15052$
Tuset V.M., Lombarte A., Assis C.A. 2008. Otolith atlas for the western Mediterranean, north and central eastern Atlantic. Scientia Marina 72 (Suppl. 1): 7-198. DOI: $10.3989 /$ scimar.2008.72s 17

Uddin S., Gevao B., Al-Ghadban A.N., Nithyanandan M., Al-Shamroukh D. 2012. Acidification in Persian Gulf-Insights from $\mathrm{pH}$ and temperature measurements. Journal of Environmental Monitoring 14 (5): 1479-1482. DOI: 10.1039/c2em10867d

Vignon M., Morat F. 2010. Environmental and genetic determinant of otolith shape revealed by a nonindigenous tropical fish. Marine Ecology Progress Series 411: 231-241. DOI: $10.3354 /$ meps08651

Vinagre C., Madeira D., Mendonça V., Dias M., Roma J., Diniz M.S. 2014a. Effect of increasing temperature in the differential activity of oxidative stress biomarkers in various tissues of the rock goby, Gobius paganellus. Marine Environmental Research 97: 10-14. DOI: 10.1016/j.marenvres.2014.01.007

Vinagre C., Maia A., Amara R., Cabral H.N. 2014 b. Anomalous otoliths in juveniles of common sole, Solea solea, and Senegal sole, Solea senegalensis. Marine Biology Research 10 (5): 523-529. DOI: 10.1080/17451000.2013.831178

Volpedo A.V., Echeverría D.D. 2000. Catálogo y claves de otolitos para la identificación de peces del Mar Argentino. Vol. 1. Editorial Dunken, Buenos Aires, Argentina.

Wilson R.R.jr. 1985. Depth-related changes in sagitta morphology in six macrourid fishes of the Pacific and Atlantic Oceans. Copeia 1985 (4): 1011-1017. DOI: $10.2307 / 1445256$

Received: 7 April 2018

Accepted: 22 May 2018

Published electronically: 30 June 2018 
